\title{
Tendencies of Telecommunication Companies Development in the Conditions of Ukrainian Society Digitalization
}

\author{
Iryna Kovshova, Nataliia Dubovyk, Nataliia Kyryliuk
}

\begin{abstract}
The article elaborates theoretical and methodologi- cal provisions and practical recommendations for development of telecommunication companies in conditions of Ukrainian society digitization. It is established that the development of Ukrainian telecommunications companies is cyclical and depends on industrial ambitions of global technology corporations, on investments in research and development, consumer requirements and needs for communication. A pilot study was conducted and a method- ology for determining the level of consumer satisfaction with telecommunication services was developed, based on the synthesis of individual assessments according to certain characteristics of services with criteria of importance of this or that characteristic for consumers. The tendency of dependence of demand for telecommunication devices and services on cumulative marketing pressure of technological and telecommunication companies in the conditions of digitalization of Ukrainian society was revealed. Consumers of innovative models of telecommunications devices are putting pressure on operators and providers and demanding the functionality of equipment, density and technological ex-cellence of telecommunications networks. These criteria become crucial when Ukrainian households choose certain companies to receive telecommunications services. The scientific novelty of the obtained results is to develop a method for determining the level of consumer satisfaction with telecommunication services based on the synthesis of individual assessments of certain characteristics of services with importance criteria of a particular characteristic for consumers.
\end{abstract}

Keywords: Telecommunications, company, digitization, trends, services, society, development, target audience.

\section{INTRODUCTION}

The development of telecommunications companies is a complex socio-economic process due to the large number of elements and the need to establish partnerships with suppli- ers, intermediaries, consumers, specific employees, society, etc. The transformation of modern socio-economic processes stimulates the development of a paradigm of joint participa- tion with the right to use temporarily the available resources of a telecommunications (TC) company and its business partners. At the same time, scientific and technological progress

Revised Manuscript Received on May 15, 2020.

* Correspondence Author

Kovshova I. O*., Professor, Department of marketing and business man-agement, National University «Kyiv-Mohyla academy», Ukraine. E-mail: iryna_kovshova@ukr.net

Dubovyk N. A., Candidate of Political Sciences, Associate Professor, De- partment of Documentation and Information, State University of Telecom- munications (Kyiv, Ukraine) E-mail: ndubovyk@bel.ua

Kyryliuk N. A., Candidate of Political Sciences, Associate Professor, De- partment of Documentation and Information, State University of Telecom- munications (Kyiv, Ukraine)

(c) The Authors. Published by Blue Eyes Intelligence Engineering and Sciences Publication (BEIESP). This is an open access article under the CC BY-NC-ND license (http://creativecommons.org/licenses/by-nc-nd/4.0/) contributes to the emergence of new technological equipment for telecommunication purposes and the formation of modern network technologies, which stimulates extensive and inten- sive development of Ukrainian telecommunications opera- tors and providers.

The combination of these socio-economic and scientif- ic and technical factors of the external environment of the company made it possible to reduce the digital divide in the regions of Ukraine, increase the power and quality of transmission of television signals, expand the geographical boundaries of the provision of telecommunication services to Ukrainian consumers and create favorable conditions for for- eign corporations applying innovative approaches to manage- ment to enter into the domestic telecommunications market. The gradual digitization of the Ukrainian society contributes to the balanced development of TC companies and enhances the competitiveness of those Ukrainian opera-tors and providers who seek to satisfy the requirements of consumers for quality round-the-clock telecommunication services without location binding.

\section{ANALYSIS OF RECENT RESEARCH AND PUBLICATIONS}

The theoretical and applied positions of companies devel- opment are partially presented in the works of such scientists: Ansoff I. [1], Daft R. [2], Doyle P. [3], Lamben J.J. [4], Abel D. [5] and others. However, the lack of universal economic and mathematical methods based on the laws of the telecom- munications market development and the analysis of require- ments of telecommunication services consumers according to individual priorities of importance, become relevant and determine the timeliness of this research.

\section{FORMATION OF GOALS}

The purpose of the article is to develop theoretical and methodological provisions and practical recommendations for the development of telecommunication companies in terms of digitization of the Ukrainian society and adaptation of existing telecommunication services to the requirements and expectations of the target audience.

Published By:

Blue Eyes Intelligence Engineering

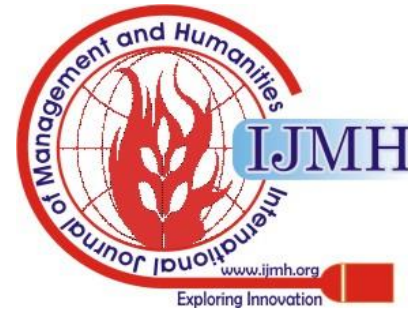




\section{Tendencies of Telecommunication Companies Development in the Conditions of Ukrainian Society Digitalization}

The theoretical and methodological basis of the study was formed by the provisions of modern socio-economic theo- ry, behavioral economics, macro-

economics and marketing. The re- search is based on the dialectical method of knowing the impact of

Ukrainian society's digitization on the development of telecommunications companies. Within this approach, general scientific and special methods were used, in particular: com- parison - to determine individual priorities of importance of different consumer groups; questionnaire - for a pilot study of the level of consumer satisfaction with telecommunication services; mathematical modeling - to evaluate the data ob- tained during the experiment and to determine the tendencies of digitization of the Ukrainian society; analysis, synthesis, induction and deduction - to interpret the findings of the study.

The basic hypotheses of the study are the following:

- Development of TC companies is cyclical and depends on the digitization of the Ukrainian society and the combined marketing pressure of technological and innovative corpora- tions.

- Consumers choose the TC services of those operators

or providers that best meet their requirements according to individual priorities of importance.

\section{PRESENTATION OF BASIC MATERIAL OF THE RESEARCH}

The Law of Ukraine «On Telecommunications» stipulates that telecommunication is the process of transmitting radia- tion, receiving signs, signals, written text, images, sounds or messages by radio, wired, optical or other electromagnetic systems [6]. Accordingly, the TC company is an independent business entity that has the rights of a legal entity and oper- ates in the specified field.

New technologies have led to revolutionary changes in the field of telecommunications. Global technology giants such as Apple Inc, Hewlett-Packard Development Co LP, Sam- sung Corp, Lenovo Group Ltd and others invest heavily in research and production of computers, laptops, tablets and smartphones of the next generation. Niantic's Pokemon Go computer game in 2016 demonstrated the potential of smart- phones and mobile devices that work autonomously and re- quire available energy level and access to telecommunication networks to provide communication [7].

The modern realities of society digitization have led to the development of TC companies in a spiral due to the influ- ence of such major factors as: production ambitions of global technology corporations; significant investment in research and development; requirements and needs of consumers of TC services in communication; capacity of TC companies (Fig. 1). The locomotive of the current stage of development of Ukrainian TC companies is the industrial capacities of glob- al technology corporations, which produce huge batches of personal computers, laptops, netbooks, tablets, smartphones and other devices with the envisaged function of connection to

Published By:

Blue Eyes Intelligence Engineering

\& Sciences Publication

(C) Copyright: All rights reserved.

telecommunication networks. Creating innovative models of TC devices requires sig-nificant investment in research and development, which of global technology corporations are aimed at promoting new devices in order to increase the number of potential and real consumers and to maximize sales of products. The current total sales of TC devices have gained huge market size and have almost reached the upper limit of current market

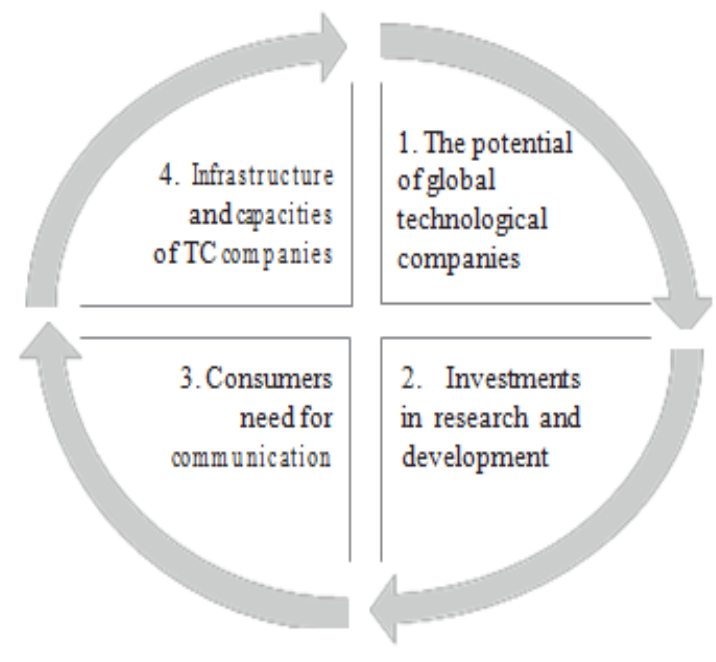

Fig. 1. The main factors that influence the development of TC companies in terms of digitization of Ukrainian society.

potential. According to the data of the Euromonitor International company [8], in 2016 over 422 million technological devices were sold worldwide to enable consumers to make telecommunications. This means that the markets for technological devices and TC services complement each other and are characterized by the same tendency to increase demand with a certain sequence of stages of active and slow growth in dynamics.

Starting from 2014-2015, there is a trend of decrease in number of TC devices sold in six of seven regions of the world: Eastern European, Western European, AsianPacific, North American, Latin American and Australian. The excep- tions are Middle Eastern and African regions. Analysis of the dynamics of sales of consumer TC devices by region of the world reveals a significant gap between the leaders (Pacific Asia, North American and Western European regions) and outsiders (Latin American, Eastern European, Middle East- ern and African regions). The Australian region is specific because of its significantly smaller population and therefore the number of potential consumers compared to other re- gions. These data provide an opportunity to set the trend of slowing consumption growth in the leading countries and to facilitate further expansion of access to TC networks in the outsider regions which include Ukraine. The Eastern European region ranks second among the seven major regions of the world in terms of the number of consumer TC units sold and the last in terms of sales per capita. 
The domestic telecommunications market is growing and attractive for technology companies and potential inves- tors looking for new opportunities and spaces for marketing products. Accordingly, the new subjects of the telecommunications market increase the level of competition and bring elements of innovative management, which are studied, adapted and then implemented by Ukrainian TC companies.

Under such market conditions, powerful global technology corporations are looking for development opportunities by col-laborating with Ukrainian TCs to increase the capabilities and capac-ities of TCs and actively engage with consumers. This makes it possible to apply complex marketing measures to the target audience: during the stimulation of the purchase of TC de- vices and at the stage of providing access to telecommuni- cation networks. The determined tendency of dependence of the demand for telecommunication devices and services on the aggregate marketing pressure of technological and TC companies in terms of digitization of the Ukrainian society is shown in Fig. 2.

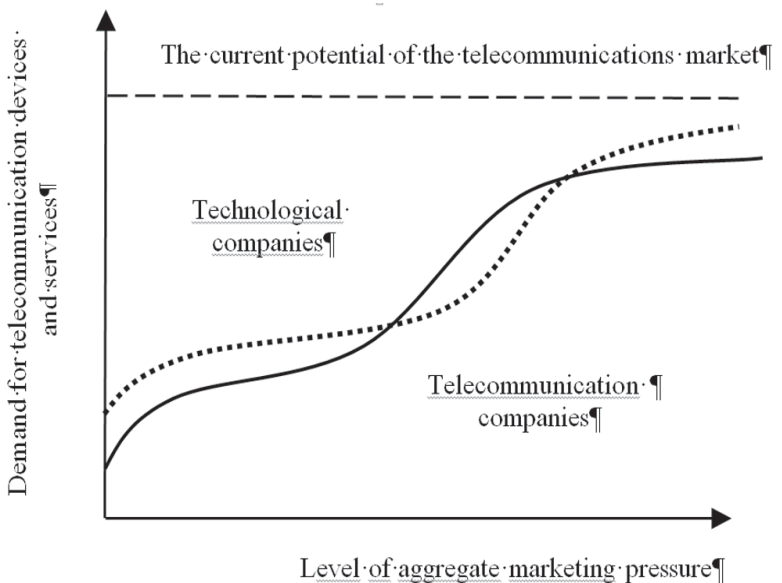

Fig. 2. Tendencies of increasing demand for telecommunication devices and services depending on the aggregate marketing pressure of technological and TC companies under conditions of digitization of the Ukrainian society.

The above mentioned technological and TC companies functions have S-shaped features, which characterize the inert increase of the demand for TC devices and services in accordance with the increase of aggregate marketing pressure in the conditions of reaching the level of current potential of the telecommunication market. By the current potential of TC market we mean the maximum possible total sales of telecommunication devices and services by all companies in a certain period. It gave the possibility to establish a

ten-dency that the use of complex marketing influence allows to increase the demand for the products of technological or TC companies due to the reaction to the increasing demand of the partner. At the same time, the subjects of activation of marketing pressure in different periods of time change ac- cording to two possible scenarios: technology companies in- crease their sales due to the promotion of TC devices, which is an impetus for the growth of the telecommunications ser- vices market; TC companies are introducing new technolo- gies and upgrading telecommunications networks, creating new requirements for devices and encouraging consumers to buy new gadgets from technology corporations.

To confirm the first basic hypothesis regarding the cyclicality of the development of TC enterprises, depending on the cumulative marketing pressure of technological and innovative companies in terms of digitization of the Ukrainian society, 147 leading international technology companies were analysed and classified by four classes [7]. This has made it possible to deduce that the powerful global class $G$ corporations, selling over 284 million units of products of their own brands, develop innovative types of TC devices

in their own scientific laboratories, stimulate scientific and technical research in the field of telecommunications and give impetus to the development of Ukrainian TC companies through partnerships. T-Class transnational companies that collectively sell more than 25 million units of TC products are relatively new and ambitious actors in the telecommuni- cations market and use certain elements of affiliate market- ing in the Ukrainian market to increase their presence in the region. The vast majority of «R» and «O» class companies assemble prefabricated components from the first two class companies to meet the individual requirements of consumers in a specific region. Thus, technological companies directly or indirectly set quality requirements for TC networks and stimulate the development of the telecommunications mar- ket in Ukraine, promoting telecommunication services of domestic TC companies, stimulating innovations, accelerating moral aging of TC devices and TC networks and creating partnerships to organize joint events. In the context of the digitization of the Ukrainian society, consumers of innovative models of TC devices also press on the TC companies and demand the provision of equipment functionality and density and technological perfection of telecommunication networks. It is established that under the influence of the requirements of the consumers of TC services, the main tendencies of the development of telecommunication networks in Ukraine are the dissemination of: first, modern fiber-optic communication lines due to the introduction of CWDM and DWDM technologies; second, telecommunication technologies for universal wireless communication with the introduction of Wi-Fi and WiMAX. These compaction and data transfer technologies allow to increase the efficiency of information exchange (quantity and speed) by one channel for different information services at different speeds [9]. As a result, there is a reduce of digital divide of Ukrainian users of TC networks by region and the gradual transition from traditional telephony to IP telephony, which provides two-way communication through the Internet or other IP networks.

Also, under the influence of con- sumer demands and according to A. Marshall's theory of de- termining the value of the company's products with marginal utility and marginal costs for its production [8], the search for innovative approaches to the management of TC companies activates, the infrastructure of the business entity improves and the capacity of telecommunication networks increases.

Published By:

Blue Eyes Intelligence Engineering

Retrieval Number: I0911054920/2020@BEIESP

DOI: 10.35940/ijmh.I0911.054920

Journal Website: www.ijmh.org

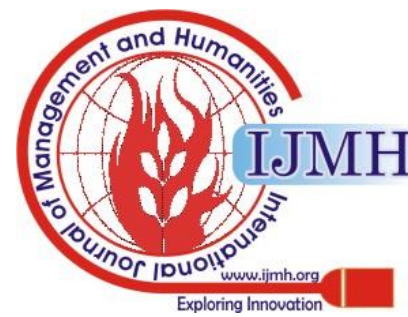




\section{Tendencies of Telecommunication Companies Development in the Conditions of Ukrainian Society Digitalization}

On the basis of the general data of a pilot study of 137 households in Ukraine, economic and mathematical models of estimation of subscribers' satisfaction level with the real state of Internet services for different segments of Ukrainian consumers were constructed. The calculations allow us to test the second basic hypothesis of the study that consumers choose the TC services of those operators or providers that best meet their requirements according to individual priori- ties of importance. The study was conducted in seven stages. At the first stage, the basic hypothesis was formulated and the main criteria for Ukrainian consumers to choose certain telecommunications companies to receive services were determined. At the second stage, a list of questions was formed and special forms for conducting

Table 1. Weighted average estimates of the importance of internet service characteristics for Ukrainian consumers (calculated basing on pilot survey data)

\begin{tabular}{|c|c|c|c|c|c|c|}
\hline \multirow[b]{2}{*}{ Indicators } & \multicolumn{6}{|c|}{ Characteristics of Internet services } \\
\hline & Traffic & $\begin{array}{l}\text { Communication } \\
\text { reliability }\end{array}$ & $\begin{array}{l}\text { Data transfer } \\
\text { speed }\end{array}$ & Tariff & $\begin{array}{l}\text { Informational } \\
\text { aecurity }\end{array}$ & $\begin{array}{l}\text { Additional } \\
\text { services }\end{array}$ \\
\hline Aggregate consumer point scores $(\Sigma W)$, points & 992 & 1061 & 1102 & 1028 & 1070 & 764 \\
\hline Number of respondents ( $i)$, persons & 137 & 137 & 137 & 137 & 137 & 137 \\
\hline Average consumer ratings $(\mathrm{Wjk})$, points & 7.24 & 7.74 & 8.04 & 7.5 & 7.81 & 5.58 \\
\hline The sum of average scores $(\Sigma \mathrm{Wjk})$, points & \multicolumn{6}{|c|}{43.91} \\
\hline Importance indices of characteristics (Wk) & 0.1649 & 0.1763 & 0.1832 & 0.1708 & 0.1778 & 0.127 \\
\hline $\begin{array}{l}\text { Average weight ratings of importance of } \\
\text { characteristics (Wk), } \%\end{array}$ & 16.49 & $1 / .63$ & 18.32 & 17.08 & $17 / / 8$ & 12.7 \\
\hline
\end{tabular}

a pilot study were developed. At the third stage, a survey was ronducted among 150 households in Ukraine to assess the criteria for selection of telecommunications services. At the fourth stage, the obtained data were systematized and their correctness was checked, as following: the data of

137 households in Ukraine were recognized as correct and

13 as incorrect. At the fifth stage, on the basis of the obtained data, the average weight estimates of the importance of characteristics of Internet services for consumers in the conditions of digitalization of Ukrainian society were calculated. At the sixth stage, the indicators of the importance of characteristics of Internet services for different age groups of Ukrainian consumers, depending on the duration of the network use and the level of income were calculated. At the seventh stage, the ob-tained results of the pilot study with regard to the obtained assessments of the importance of Internet services characteristics were analyzed and conclusions were formulated to confirm the basic hypothesis.

The simulation is presented in a tabular format containing three interconnected blocks of metrics. The first block includes data from the questionnaires on average actual consumer rat- ings, divided by specific segments.

The second block summa- rizes the average-weighted estimates of the importance of Inter- net service characteristics for each selected segment. The third block presents the results of calculations of two types of esti- mates for each segment: arithmetic averages and weighted aver- ages. The proposed methodology of economic and mathematical modelling allows, unlike others, to synthesize individual actual estimates on the characteristics of TC services, allocating con- sumers to different segment groups and taking into account the criteria of importance of a particular property. It is also possible to determine the actual level of customer satisfaction with the services by using the specified model of consumer preferences, to identify possible signs of differentiation, to find undervalued characteristics and to improve their quality.

Summarized data for modelling based on a pilot study of Ukrainian households are presented in Table 1. According to the proposed methodology, the basic properties of Internet services are identified, which include: traffic, communication reliability, data transfer speed, tariff, Informational security and availability of additional TC services [7]. According to the data obtained, all the above-mentioned an consumers. Applying the rank method [10], a general distribution was made according to which the most important feature is Internet speed (18.32\%); in second place - informational security (17.78\%); third - communication reliability $(17.63 \%)$; fourth - tariff policy (17.08\%); fifth - traffic importance (16.49 \%); in last place - availability of additional support services $(12.7 \%)$. The proposed methodical approach to the formation of client-oriented offers of TC companies provides for the pos

sibility of establishing average weighted ratings of im-portance of characteristics (Wk) in different segments. According to the analysis of the pilot study, the following features of segmentation were identified: consumer age, experience of Internet use, income level. The results of the study of changes in average weight estimates by different age groups of Ukrainian consumers are presented in Table. 2. Thus, only consumers under 30 years old prioritize Internet speed. For consumers aged from 31 to 60 years old (two age groups) informational security is of paramount importance (especially after the viral attacks of programs in 20162019 Petya.A, Petya.D, Trojan.Ransom.

Petya, PetrWrap, NotPetya, ExPetr, GoldenEye), and for seniors, the terms of the tariff plan are a priority. The second priority for Ukrainian consumers under the age of 30 and over 60 (two groups) is communication reliability.

Published By:

Blue Eyes Intelligence Engineering

\& Sciences Publication

(C) Copyright: All rights reserved.

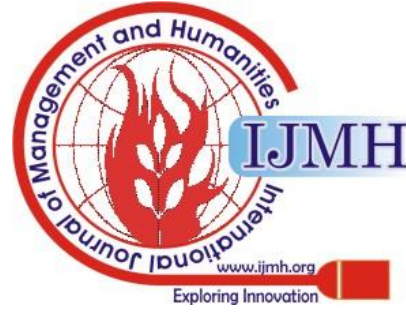


For consumers from 31 to 45 years old Internet speed is in second place, and for the age group of consumers from 45 to 60 years, the second place is taken by a tariff plan. The third prior- ity for Ukrainian consumers under 30 years old is traffic.

For consumers from 31 to 45 years old, third place means reliable connection, and for the age group of consumers over 45 years old (two age groups) it means Internet speed. Addi-tional services across all segment groups rank last, similar to overall average weighted ratings of features im- portance.

The second segmentation is the division of Ukrainian consumers according to the duration of the Internet use. The main objective of implementing this separation is to assume that there is a connection between Internet experience duration and

the growing importance of char- acteristics of «Speed», Reliabili- ty», and Informational security».

Table 2. Indicators of importance of Internet service characteristics for different age groups of Ukrainian consumers (calculated basing on pilot survey data)

\begin{tabular}{|c|c|c|c|c|c|c|}
\hline \multirow[b]{2}{*}{ Indicators } & \multicolumn{6}{|c|}{ Characteristic ofInternetservices } \\
\hline & 愚 & 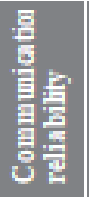 & 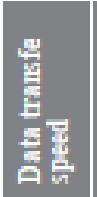 & 屏 & 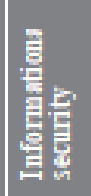 & 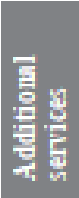 \\
\hline \multicolumn{7}{|c|}{ Aggregntecousmer point scores by groups $(2 \mathrm{~W})$, points: } \\
\hline$-\operatorname{fon} 16$ to 30 ycas old & 334 & 348 & 362 & 320 & 318 & 264 \\
\hline- fou 31 to 45 ycas old & 430 & 479 & 502 & 448 & 508 & 322 \\
\hline$-\operatorname{fon} 45$ to 60 yces old & 188 & 180 & 196 & 202 & 210 & 150 \\
\hline- mors than 60 yeas old & 40 & 54 & 42 & 58 & 34 & 28 \\
\hline \multicolumn{7}{|c|}{ Namber of reppandents (i) pervanx } \\
\hline - fou 16 to 30 ycas old & \multicolumn{6}{|c|}{44} \\
\hline$-\operatorname{fom} 31$ to 45 year old & \multicolumn{6}{|c|}{60} \\
\hline$-\operatorname{fon} 45$ to 60 ycas old & \multicolumn{6}{|c|}{26} \\
\hline$-\operatorname{mos}$ than 60 ycas old & \multicolumn{6}{|c|}{7} \\
\hline \multicolumn{7}{|c|}{ berage cansumer rafings $\overline{(\mathrm{W} J \mathrm{~J}}$, paints } \\
\hline$-\operatorname{fon} 16$ to 30 ycas old & 7.59 & 791 & 8.23 & 727 & 723 & 6.00 \\
\hline -fom 31 to 45 yeses old & 7.17 & 798 & 837 & 7.47 & 8.47 & 537 \\
\hline$-\operatorname{fom} 45$ to 60 ycas old & 723 & 692 & 7.54 & 7.77 & 8.08 & 5.77 \\
\hline -mers than 60 yeas old & 5.71 & 7.71 & 6.00 & 829 & 4.86 & 4.00 \\
\hline \multicolumn{7}{|c|}{ The san of average soures $(2 \overline{W F})$ paints } \\
\hline$-\tan 16$ to 30 ycas old & \multicolumn{6}{|c|}{4423} \\
\hline$-\operatorname{fon} 31$ to 45 yces old & \multicolumn{6}{|c|}{44.82} \\
\hline$-\operatorname{fom} 45$ to 60 ycos old & \multicolumn{6}{|c|}{4331} \\
\hline -mars than 60yces old & \multicolumn{6}{|c|}{3657} \\
\hline \multicolumn{7}{|c|}{$\begin{array}{l}\text { berage weight rafingx of impartance of cha racteristix } \\
\qquad \text { by cansamer graups (WK. } 96\end{array}$} \\
\hline - fom 16 to 30 ycas old & 17.16 & 17.88 & 18.60 & 16.44 & 1634 & 13.57 \\
\hline- foun 31 to 45 ycas old & 1599 & 17.81 & 18.67 & 16.66 & 18,89 & 1197 \\
\hline$-\operatorname{fom} 45$ to 60 ycas old & 16.70 & 1599 & 17.41 & 1794 & 18.65 & 1332 \\
\hline- mos: than 60 ycas old & 15.63 & 21.09 & 16.41 & 22.66 & 1328 & 1094 \\
\hline
\end{tabular}

Table 3. Indicators of Internet services characteristics importance by Ukrainian consumers, according to the duration of the Internet use (calculated basing on pilot survey data)

\begin{tabular}{|c|c|c|c|c|c|c|}
\hline \multirow[b]{2}{*}{ Indicators } & \multicolumn{6}{|c|}{ Characteristics of nnteruetservices } \\
\hline & 宦 & 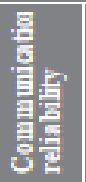 & 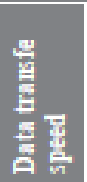 & 岸 & 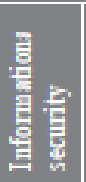 & 䆣 \\
\hline \multicolumn{7}{|c|}{ A ggreglecousmer point scores by gro ups ( $\mathrm{WW}$ ), points: } \\
\hline -up to 3,000 uah & 266 & 274 & 272 & 256 & 256 & 226 \\
\hline$-3000-6,000$ uah & 268 & 304 & 310 & 316 & 300 & 206 \\
\hline$-6000-10,000$ uah & 308 & 323 & 350 & 316 & 346 & 222 \\
\hline - over 10,000 uah & 150 & 160 & 170 & 140 & 168 & 110 \\
\hline \multicolumn{7}{|c|}{ Namber of repandents (i) pernanx } \\
\hline -up to 3,000 uah & \multicolumn{6}{|c|}{36} \\
\hline$-3,000-6,000$ uah & \multicolumn{6}{|c|}{40} \\
\hline$-6,000-10,000$ uah & \multicolumn{6}{|c|}{42} \\
\hline - orcr 10,000 uah & \multicolumn{6}{|c|}{19} \\
\hline \multicolumn{7}{|c|}{ berage cansumer rafings $\overline{(\mathrm{WF} / \mathrm{j}}$, paints. } \\
\hline -up to 3,000 uah & 739 & 7.61 & 7.56 & 7.11 & 7.11 & 6.28 \\
\hline$-3,000-6,000$ uah & 6.70 & 7.60 & 7.75 & 790 & 7,50 & 5.15 \\
\hline$-6,000-10,000$ uah & 733 & 7.69 & 833 & 7.52 & 8,24 & 529 \\
\hline - orcr 10,000 uah & 7.89 & 8.42 & 8.95 & 737 & 8.84 & 5.79 \\
\hline \multicolumn{7}{|c|}{ The san of average wares $(\overline{2} \overline{W F L}$ paints } \\
\hline - up to 3,000 uah & \multicolumn{6}{|c|}{43.06} \\
\hline$-3,000-6,000$ uah & \multicolumn{6}{|c|}{42.60} \\
\hline$-6,000-10,000$ uah & \multicolumn{6}{|c|}{44.40} \\
\hline- orc 10,000 uah & \multicolumn{6}{|c|}{4726} \\
\hline \multicolumn{7}{|c|}{ 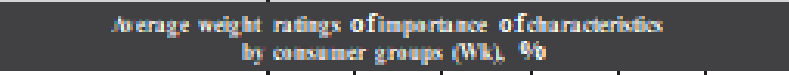 } \\
\hline -up to 3,000 uah & 17.16 & 17.68 & 17.55 & 1652 & 16.52 & 14.58 \\
\hline$-3,000-6,000$ uah & 15.73 & 17.84 & 18.19 & 18.54 & 17.61 & 12.09 \\
\hline$-6,000-10,000$ uah & 16.51 & 1732 & 18.77 & 1694 & 18.55 & 1190 \\
\hline - ovar 10,000 uah & 16.70 & 17.82 & 18.93 & 1559 & 18.71 & 1225 \\
\hline
\end{tabular}

The calculation of average weight consumer ratings is presented in Table 3.

The given data on estimations of importance of characteristics of client-oriented offers of TC company by segment groups depending on the duration of use also differ considerably among themselves. For consum-ers-beginners the priority is speed of Internet and availability of additional services from operator or telecommunications provider. For consumers who use Internet from 1 to 5 years, the most important are «Tariff» and «Informational security» options. For those who use Internet from 5 to 10 years, the "Speed" and "Informational security" are essential. At the same time, consumers who have been using Internet for a long time, prioritize "Speed", "Communication Reliability" and "Informational security" options. The last places in all segment groups, except for the newcomers, belong to the ratings of importance of «Traffic» and «Availability of additional services» options. Thus, the study found a link between Internet experience and increasing importance of the presence of "Speed", "Reliability", and "Infor-mational security" during consumers'

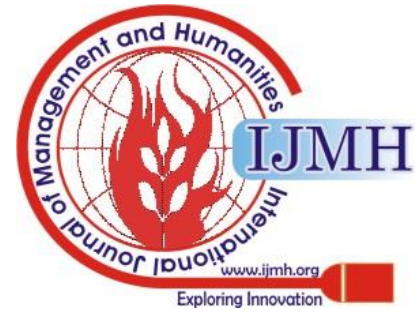




\section{Tendencies of Telecommunication Companies Development in the Conditions of Ukrainian Society Digitalization}

The third segmentation is the division of Internet service users according to their income level. The main task of implementation of such division is to assume that there is a relationship between the level of revenue of users and importance of the characteristic "Tariff policy of TC Company». Calculations of average weight estimates of Ukrainian consumers are presented in Table 4. The above data allowed to establish that for consumers of Internet services with lowincome (up to 3000 uah) "Communication" and "Speed" are the main priori- ties, and "Tariff" option takes only the third place. At the same time, "Tariff" and "Speed" are of the utmost im- portance for consumers with income level from 3,000 to 6,000 uah. For consumers with an income level of more than 6,000 uah (two groups) the most important are "Speed" and "Information security" characteristics of the Internet.

Third place for all consumers, ex-cept for the lowest income group, is taken by the «Reliability of communication» characteristic.

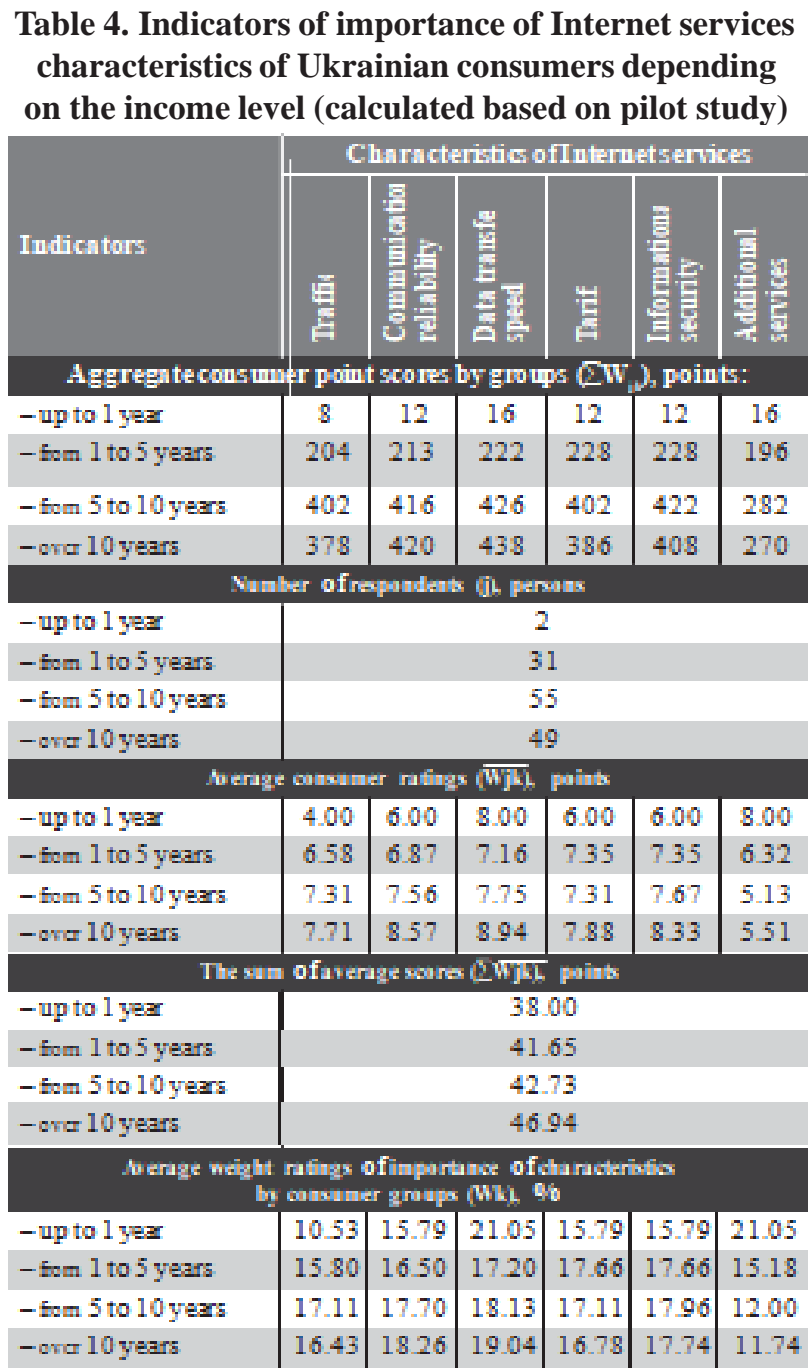

The availability of additional services from provider is not again a priority.

Thus, in the process of the research a certain correlation was found between the level of consumer's income and the importance of the "Tariff" characteristic. Only low-income con-sumers (up to 3,000 uah) are more loyal to TC enterpris- es that provide low-cost Internet services. In all other cate- gories of clients with incomes of 3,000 uah and more, the pricing policy of telecommunication operators or providers is second to last.

The conducted research has confirmed the second basic hypothesis concerning changes of importance estimates of Internet services characteristics depending on various signs of segmentation (age of the user, level of income, experience of Internet use).

\section{CONCLUSIONS}

The study found that the development of TC companies is cyclical and depends on the digitization of the Ukrainian society and combined marketing pressure of technological and innovative corporations. Consumers of innovative models of TC devices are pressing on TC companies and require equip- ment functionality and density and technological perfection of telecommunication networks. These criteria are critical when consumers choose telecommunication services of TC companies.

The assessment of consumer preferences of custom-erori-ented offers of domestic operators and providers allowed to identify the following trends in the development of telecom- munications companies in the digitalization of Ukrainian society: consumers choose telecommunications services of those operators or pro-viders that best meet their require- ments according to individual priorities; different social groups of customers have differences in preferences that cor- respond to certain points (for consumers who are temporarily out of work, the main priority is the availability of entertain- ment content; for retirees - tariff; for students communica- tion; for employees - informational security; for middle-rank and top managers - speed); there is a correlation between the level of revenue of final customer, the volume of packages and the importance of the «Tariff Plan» characteristic (con- sumers who receive the minimum and average packages of telecommunications services are more loyal to those opera- tors and providers who offer lower prices or discounts; for the households that use unlimited packages pricing policy is less important).

The scientific novelty of the obtained results is to develop a methodology for determining the level of satisfaction of consumers of TC services on the basis of synthesis of individual assessments on certain char-acteristics of TC services with criteria of importance of a particular characteristic for consumers.

\section{REFERENCES}

1. Ansoff I. Novaia corporativnaia strategiia [New corporate strategy] / I. Ansoff, J. McDonnell. - SPb. : Piter Dom, 2009. 416 p.

2. Daft R. L. Organization Theory / translation from English E. M. Ko- rotkov. - M.: UNITY-DANA, 2012. - 736 p.

3. Doyle P. Marketing Management and Strategies / translation from English under the editorship of Y. N. Kapturevsky. - SPb. : Peter, 2002. -544 p.

4. Lamben J.-J. Market Oriented Management / J.-J. Lamben, R. Chum- pi-tas, I. Schuling; translation from English under the editorship of V. B. Kolchanov. - 2nd ed. - SPb.: Peter, 2014 .-718 p. 
5. Abell D. E. Defining the Business: the Starting Point of Strategic Planning / D. E. Abell. - NJ: Prentice-Hall. 1980. - 450 p.

6. The Law of Ukraine "Pro telecomunicatsii" ["On Telecommunications"] from 04.06.2017 [Electronic resource]. - URL: www.zakon3. rada.gov.ua/laws/show/1280-15/page

7. Kovshova, I.O. (2018), Marketingovyi menedzhment: teoriia, metodo-logia, praktika [Marketing Management: Theory, Methodology, Prac-tice], monograph, FOP Vyshymyrskii, Herson, Ukraine, 516 p.

8. Consumer Electronics. - URL : https://www.portal.euromonitor.com/ portal/statistics/tab

9. Gnatyuk C. Rozvitok merezhi Internet ta online-ressoursov v Ukraine: problemy i perspektyvy [Electronic resource] [Development of In- ternet and Online Resources in Ukraine: Problems and Prospects [Electronic resource] / - URL: www.old.niss.gov.ua/monitor/ April2009/1.htm

10. Churchill, G.A. Marketingovye issle- dovaniia [Marketing Research] / G.A. Churchill, D. Jakobucci. - St. Peters-

\section{AUTHORS PROFILE}

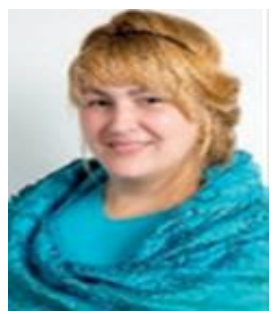

Dr. Iryna Kovshova, is a professor a Department of Marketing and Business Management, National University "Ky- ivMohyla Academy", Ukraine. Her re- search works are focused on theory and practice of marketing management, be- havioral economics, neuromarketing tech- nologies, methodology of making optimal management solutions with application of economy and mathematica models. The main focus of her scientific researches: Improvement of company efficiency by means of marketing management tools and neuromarketing technologies. The author's courses of lectures deliv- ered in National University "Kyiv-Mohyla Academy": Marketing manage-ment; Management solutions theory; Marketing policy of communications; Change management. The author has more than 65 publications. The most important of them for published for the last two years in science-based editions: Kovshova I. Marketing Management: Theory, Methodology, Practice, monograph, Ukraine. 2018. 516 p. Kovshova I., Sydorenko O., Zubko T. Prospective trends in neuromarketing tools of the food industry in view of Ukrainian society digitalization. International Journal of Recent Technology and Engineering (IJRTE). 2019. Volume-8. Issue 3C. https://orcid.org/0000-0001-9013-0180

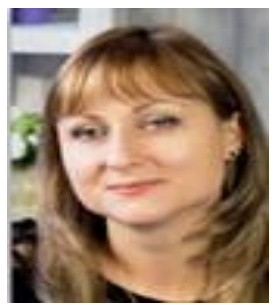

Nataliia Dubovyk, Candidate of Political Sciences, Associate Professor, Depart- ment of Documentation and Information, State University of Telecommunications (Kyiv, Ukraine). Her research works are focused on social technology. Main areas of research: communica- tion technologies, image communications, public relations technologies, political analysis, political management, commu- nication studies and manipulative tech- nologies in corporate management. The following courses were uniquely designed for the State University of Telecommuni- cations: Imageology, Theory and Practice of Public Relations, Political Science, Ethics of Business Communication and Rhetoric. The author has more than 40 publications. The most important of them were published over the last two years in science-based editions:

Dubovyk N.A, Kyryliuk N.A Political science and political technolo- gies: a textbook. Ukraine. 2020. 166 p.

Dubovyk N. A., Kyryliuk N. A. Retrospective study of the concept «image»: American, European and national experience. Gilea: scientific bulletin, 2018. Kyiv, Ukraine. Edition 138 (3). Part 3. Political science. p. 18-21. URL: http://www.gileya.org/index.php?ng=library\&cont=long\&id=166 Kyryliuk N. A., Dubovyk N. A. Special aspects of communication sup- port of entrepreneurship in Ukraine // Challenges and prospects for the development of social sciences in Ukraine and EU countries: a comparative analysis: Collective monograph. Riga: Izdevniecība «Baltija Publishing», 2019. P.119-131.

Kyryliuk N. A., Dubovyk N. A. Media and communication manipulation in Contemporary Politics. Gilea: scientific bulletin, 2019. Kyiv, Ukraine. Edition 150 (№11). Part 3. Political science. p. 36-39. URL: http://www. gileya.org/index.php?ng=library\&cont=long\&id=214

Full member of the editorial board of the scientific publication Social and Humanitarian Bulletin: a collection of scientific works of social sciences and humanities - creative workshop "New Course". Kharkiv, Ukraine https://orcid.org/0000-0003-0151-9480

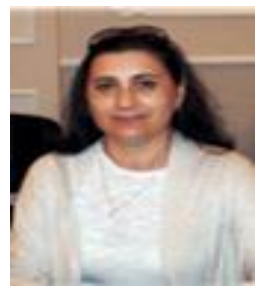

Nataliia Kyryliuk, is a candidate of polit- ical science (Ph. D.), Associate Professor, Department of Documentation and Infor- mation, State University of Telecommuni- cations (Kyiv, Ukraine)

in the State University of Telecommu- nications of Ukraine. Her research works are focused on communication theory and practice, political analysis and forecast- ing, political management and marketing. The main goals of her researches: the ap- plication of technologies of political anal- ysis, monitoring and forecasting of the managerial decisions making process. The following courses were uniquely designed for the State University of Telecommunications: Theory and Practice of Communications, Information and Analytical Activity, Political Technologies, Political Analytics and Forecasting. Author of more than 40 publications. The most important of them were published over the last two years in science-based editions:

Kyryliuk N. A., Dubovyk N. A. Special aspects of communication sup- port of entrepreneurship in Ukraine // Challenges and prospects for the development of social sciences in Ukraine and EU countries: a comparative analysis: Collective monograph. Riga: Izdevniecība «Baltija Publishing», 2019. P.119-131.

Kyryliuk N. A., Dubovyk N. A. Media and communication manipulation in Contemporary Politics. Gilea: scientific bulletin, 2019. Kyiv, Ukraine. Edition 150 (№11). Part 3. Political science. p. 36-39. URL: http://www. gileya.org/index.php?ng=library\&cont=long\&id $=214$

Dubovyk N. A., Kyryliuk N. A. Retrospective study of the concept «image»: American, European and national experience. Gilea: scientific bulletin, 2018. Kyiv, Ukraine. Edition 138 (3). Part 3. Political science. p. 18-21. URL: http://www.gileya.org/index.php?ng=library\&cont=long\&id=166 Dubovyk N.A, Kyryliuk N.A Political science and political technolo- gies: a textbook. Ukraine. 2020. 166 p. https://orcid.org/0000-0003-0379-3707

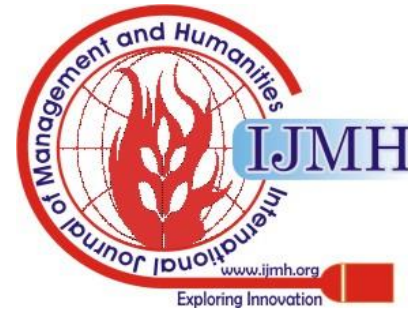

